\title{
TRAÇOS E ENLACES DO IMAGINÁRIO
}

Cláudia Mentz Martins 1

ORCID: https://orcid.org/0000-0003-3757-0800

ORCID: https://orcid.org/0000-0002-4882-627X

Pensar no Imaginário, considerando o seu manancial teórico e crítico, e nas redes de simbolização que a humanidade tem feito uso para se representar ao longo do tempo, é um dos objetivos centrais da Téssera. A proposta da revista, em divulgar estudos e crítica do imaginário e suas relações com áreas de conhecimento afins, lança-se à discussão e à exploração das bordas dos processos de articulação entre metáforas, imagens, sinestesias e sentidos que a literatura e a as demais artes materializam.

Contudo, a publicação das reflexões e análises dos diferentes olhares sobre o texto literário não tenciona promover a cristalização de saberes, pois o fluxo de atuação dos imaginários se corrói e se altera a partir de cada nova leitura e apreciação crítica. Afinal, as obras literárias e/ou artísticas se ampliam em seus dizeres, e agregam possibilidades de leituras que enriquecem seus sentidos possíveis. Sob essa perspectiva, não se pode esquecer que, para Gilbert Durand (1998), o imaginário se configura a partir de um pluralismo das imagens que se organizam, em uma estrutura sistêmica, e que são continuamente heterogêneas. O imaginário não se caracteriza pela estagnação, ao contrário, está sempre em contínuo fazer-se. Sobre essa questão, Durand explicita que:

O imaginário não é uma disciplina, [...] radica no além, na realidade do mundus imaginalis que, como outrora afirmei paradoxalmente a propósito do símbolo, é "epifania de um mistério", faz ver o invisível através dos

1 Professora associada da Universidade Federal do Rio Grande (FURG). Membro do GT "Imaginário, representações literárias e deslocamentos culturais" (ANPOLL). É uma das líderes do grupo de pesquisa "Literatura, Imaginário e Poéticas da Contemporaneidade", cadastrado no CNPq. É coorganizadora dos livros Literatura: imaginário, vozes femininas e escritas do eu. (2019); Práticas do ensino de literatura: do cânone ao contemporâneo. (2017); Outras vozes, outros olhares: imaginário, vozes femininas e escritas do eu (2016). E-mail de contato: claudiamartins@furg.br

2. Professor associado da Universidade Federal de Pernambuco (UFPE). Membro do GT "Imaginário, representações literárias e deslocamentos culturais" (ANPOLL). Lidera o grupo de pesquisa SUTRA Subalternidades, Transculturalidade e Perspectivas Decoloniais, cadastrado no CNPq. E-mail de contato: ricardo.postal@ufpe.br 
significantes, das parábolas, dos mitos, dos poemas... Existe em todas as culturas que, durante muito tempo, viveram das "técnicas do invisível" [...] (DRAND, 1996, p. 243-244)

O próprio Durand (1983) também destaca que a literatura possui uma linguagem que favorece a transmissão do imaginário, pois o discurso literário propicia uma expressão indireta, a ser codificada, o que potencializa as imagens. Portanto, ao lidar com o texto literário, a tarefa do crítico do imaginário é localizar as imagens, os símbolos, os mitos e fazer notar suas interrelações, suas constelações dentro de um universo pulsante. Para melhor desenvolver essas ideias, é imprescindível trazer Gaston Bachelard (2009) à discussão, pois ele salienta as relações indissociáveis entre as imagens e a palavra - cerne do discurso literário - para constituição do indivíduo e de sua psique. Ele discorre que:

[as] imagens literárias dão esperança a um sentimento, conferem um vigor especial à nossa decisão de ser uma pessoa, infundem uma tonicidade até mesmo à nossa vida física. [...] Vitalizam-nos. Por elas a palavra, o verbo, a literatura, são promovidos à categoria de imaginação criadora. O pensamento, exprimindo-se numa imagem nova, se enriquece ao mesmo passo que enriquece a língua. O ser torna-se palavra. A palavra aparece no cimo psíquico do ser. A palavra se revela com o devir imediato do psiquismo humano, dando oportunidade para que os que lerem suas análises aprendam também a realizar suas observações atentas para o pulsar momentaneamente captável da imaginação. (BACHELARD, 2009, p.03).

Tão importante quanto abordar os aspectos teóricos do imaginário é verificar como diferentes estudiosos sistematizam as elucubrações sobre o tema. E, para isso, o presente número atemático da Téssera garantiu espaço para que fossem abordados os mais diversos assuntos sobre os quais os pesquisadores têm se debruçado.

No artigo de abertura, "O absurdo existencial em Horacio Quiroga: uma análise da natureza à luz do conceito de topoanálise de Gaston Bachelard", ao se interrogar sobre a atuação do espaço na contística de Quiroga, Ayanne Larissa Almeida de Souza faz perceber de que modo a existência humana, tensionada pelo o que Albert Camus denominou de "absurdo existencial", é ignorada e mesmo hostilizada na construção imagético-espacial do conto analisado, "A la deriva". Ao longo de sua exposição, conforme anunciado do título, a autora utiliza-se do conceito de 'topoanálise' trazido por Gaston Bachelard. Com o discorrer do texto, verifica-se que o embate entre a consciência humana da inevitabilidade da morte e o entorno, que ignora tal inquietação, promove o absurdo tão bem apresentado pelo escritor uruguaio. 
O cruzamento teórico que fundamenta as perspectivas e estudos sobre o imaginário segue sendo apresentado na abordagem da psicologia arquetipal de James Hillman, assunto do artigo "Imágenes míticas y oníricas: un análisis desde la psicología arquetipal”, de José Francisco da Silva Filho. Ao longo do texto, é apresentado um panorama do pensamento de Freud e de Jung sobre imagens oníricas, suas relações com os mitos e o prosseguimento dessa perspectiva para se abordar as relações com o mundo imaginal. O estudo da dramatização, ou da narrativização dessas imagens dos sonhos, ganha relevância para compreender os percursos humanos de representação. Com a proposta de desenvolver as questões referentes à mitopoética, o autor se vale ainda dos estudos de Mircea Eliade, Ernst Cassirer e Gaston Bachelard que fazem a abordagem desse tópico sob um prisma míticosimbólico.

As relações instauradoras dos imaginários convergentes seguem sendo explanadas no texto “Os Infernos na Divina Comédia' e nos afrescos da capela Scrovegni: contatos entre Dante Alighieri e Giotto di Bondone no século XIV”, de Thatiane Piazza de Melo. Aqui, a circulação no âmbito das imagens medievais sobre o castigo aos usurários gera, numa conversa tomada como provável de ter acontecido entre Dante e Giotto, um conjunto de afrescos na capela Scrovegni. A autora aproxima as figurações infernais do Juízo Final da capela ao que se lê na Divina Comédia. O imaginário da época, portanto, agencia modos de figuração similares em artistas que estavam num mesmo espaço no mesmo período, e o que o artigo ressalta, portanto, é um procedimento de mitanálise nos moldes de Gilbert Durand, que se propõe a "identificar os grandes mitos diretores dos momentos históricos e dos tipos de grupos e de relações sociais. [...] já que frequentemente as instâncias míticas estão latentes e difusas numa sociedade.” (Durand, 1979, p. 313).

Geam-Karlo Gomes visita a vigorosa tradição nordestina da literatura de cordel para investigar a figura história de Antonio Conselheiro sob a perspectiva da psicologia analítica. Em "O imaginário no cordel Antonio Conselheiro: o profeta do sertão", o autor faz uma breve consideração sobre a literatura de cordel para chegar à noção de imaginário como uma produção simbólica "complexa" e "movediça" em que as percepções subjetivas e do universo coletivo se entrelaçam para configurar a poética cordeliana como matriz do imaginário. Após conceituar arquétipo e mito, Geam Karlo-Gomes identifica os arquétipos da Criança Divina, do Velho Sábio e do Salvador na constituição do mito do herói Antonio Conselheiro na obra citada. 
Ana Maria Lisboa de Mello fecha este número com um delicado estudo comparativo das Tapeçarias de Cluny com a poesia da poeta portuguesa Maria Tereza Horta. $\mathrm{O}$ artigo "'O que faço da minha eternidade'? - O imaginário medieval em A dama e o unicórnio, de Maria Teresa Horta" recupera o percurso histórico das tapeçarias medievais "La Dame à la Licorne", sua transposição de Boussac para o Museu Cluny - Museu Nacional da Idade Média, em Paris, bem como os primeiros estudos e referências literárias a essa arte que tem fascinado admiradores e suscitado muitas interpretações ao longo do tempo. Partindo de uma análise intrínseca dos poemas de Horta, Ana Lisboa alcança uma leitura simbólica do "chifre" como portador de sentido sexual e espiritual e observa a analogia entre a tecedura do tapete e a tessitura literária. Além de resgatarem a união corporal e espiritual e o sentido religioso, Ana Lisboa realça, ainda, que os poemas de Horta despertam a condição feminina, "a memória subjugada das mulheres". Elementos assim tão ricamente explanados garantem a eternidade das tapeçarias do Museu Cluny e da poesia de Maria Tereza Horta.

Como é possível perceber pelos artigos que compõem este número, a Téssera dá seguimento a sua proposta de ser um espaço comprometido com as investigações do imaginário, sobretudo, em obras literárias, constituindo-se como referência às pessoas que se dedicam ao assunto.

\section{Referências}

BACHELARD, Gaston. $O$ ar e os sonhos: ensaio sobre a imaginação do movimento. São Paulo: Martins Fontes, 2009.

DURAND, Gilbert. Figures mythiques et visages de l'œuvre. Paris: Berg International, 1979.

DURAND, Gilbert. Mito e sociedade: a mitanálise e a sociologia das profundezas. [Lisboa]: A regra do jogo, 1983.

DURAND, Gilbert. Campos do imaginário. Tradução de Maria João Batalha Reis. Lisboa: Instituto Piaget, 1998. 